\title{
Insiders or Outsiders Within? Immigrants in the Finnish Labor Market
}

\author{
ANNIKA FORSANDER, Ph.D., Researcher \\ CEREN, Centre for Research on Ethnic Relations and Nationalism, \\ Swedish School of Social Sciences, \\ University of Helsinki, Finland
}

\begin{abstract}
This article focuses on the position of immigrants on the Finnish labor market in the context of recent migration history and the disintegration of the traditional paid-work society. Finland is a so-called late immigration country, where a positive trend in migratory movements did not begin until the beginning of the 1990s and where the labor migration phase after WWII was experienced not as an immigration country but as one of emigration. One outcome of this is that immigrants are treated in society as a social burden rather than a labor resource. Results of an empirical study concerning immigrants in the Finnish labor market indicate that more than a half of immigrants who have been residing in Finland for several years have an unstable labor market career, and almost one-third of them are in the margins of the Finnish labor market. It seems that in Finland, as in the labor markets in many other postindustrial societies, immigrants are acting as a buffer against upswings and downswings in the economy.
\end{abstract}

Keywords: immigration, labor migration, labor policies

\section{Introduction - Migrations of labor in the Finnish context}

For most of its history, Finland has been a country of out-migration, and it only became one of in-migration at the beginning of the 1990s, as net migration became positive. In the European context, Finland is a latecomer as a country of in-migration. Much like other nations on the outskirts of Europe - Portugal, Spain, Italy, Greece and Ireland - Finland was mainly a labor-sending country until a few decades ago, when economic development altered the situation. There are over one million persons of Finnish descent and their descendants. 
Before the 1990s, migration to Finland typically consisted of return migrants who had left Finland earlier. Western industrial nations built their postwar wealth by recruiting millions of people from different parts of the Mediterranean. In Finland, the labor shortage did not reach similar proportions. The baby-boom generation was enough to guarantee the supply of labor. Driven away by unemployment created by a revolution in the structure of production, many people emigrated to Sweden and even further away. (Nieminen 1999, 34.)

Finally, in the late 1980s and the early 1990s, Finland became a real destination for immigration: more people arrived in the country than departed. Immigrants also became more ethnically diverse. In the first years of the 1990s Finland received asylum seekers especially from Somalia and the former Yugoslavia. This was also the beginning of what is termed ethnic return migration, referring to Finns who moved from the former Soviet Union. Even with the coming of refugees and return migrants from the former Soviet Union, marriage still remains one of the most common reasons for immigrating to Finland (Ylänkö 2000)

Finland's immigration policy has not been determined by labor market considerations; instead it has developed as a result of external pressures, such as international agreements, or on the basis of ethnic loyalty. ${ }^{1}$ The separation of immigration and labor market policies is reflected in issues directly related to immigrants as well as administrative practices that indirectly touch upon immigration issues: because a clear-cut vision is lacking, officials are in a very powerful role at the practical level as architects of immigration policy.

In terms of the labor market, immigrants may be divided in two groups:

1) Labor-force immigrants, who immigrate because they or a family member have a job in Finland.

2) Non-labor force immigrants, who immigrate to Finland for reasons other than work. This group includes refugees, return migrants from the former Soviet Union and immigrants who move to Finland because of marriage or other family reasons.

In Finland, unlike most other industrial countries, immigrants who arrive for reasons other than employment make up a significantly larger group than immigrants coming for employment, who comprise a small but growing cluster. Although a majority of immigrants living in Finland moved there for other than employment reasons, most are in the labor market nonetheless. The employment rate of immigrants is considerably lower than among the rest of the population, and unemployment among those who are part of the workforce is many times greater compared with the rest of the

\footnotetext{
I refer here to what is called ethnic return migration and began in 1991 to Finland from the former Soviet Union, meaning immigration based on the ideology of kindred peoples. Similar immigration programs exist also in Germany and Greece.
} 
population (Forsander 2002). This situation presents a challenge: how to employ those immigrants in the workforce who did not immigrate as a consequence of a demand for their specific kind of labor.

As a consequence of the mass unemployment resulting from the early 1990s recession, the immigrants' employment rate deteriorated quickly, both in the case of immigrants who had resided in the country for a longer period as well as newcomers. Finland's immigrant population grew rapidly during the recession years, at the same time as many who had arrived earlier were also suffering from unemployment. Immigrant unemployment finally started to decline in the mid-1990s. The decline in unemployment is above all a consequence of an improved economy, but policy measures such as training and government-sponsored employment opportunities have been essential (e.g. Forsander \& Alitolppa-Niitamo 2000).

Finland's immigration situation is different compared to other Western countries as not once in history has the labor shortage reached proportions that would result in a broad demand for foreign labor. ${ }^{2}$ In many other Western industrial nations, the economic growth that began in the 1950s spurred governments to recruit labor particularly from Southern Europe and other Mediterranean countries. In many European nations, immigrant workers became established minorities in time, as families followed their providers and the second and third generations were born in the new country. In recent decades, the selective recruitment of workforce has given way to increasingly tight immigration controls all over Western Europe. In spite of controls, immigrant minorities continue to grow, mainly due to family reunification, asylum seekers and illegal immigration. Especially after it became a member of the European Union, Finland has designed and implemented measures that regulate immigration together with the rest of Europe, even though the volume of immigration to Finland is lighter than elsewhere in Europe.

The economic and political development of the period of independence has not encouraged an understanding of immigration as an economic resource. Therefore, immigration has been based on grounds other than economic ones: marriage, the need for asylum or, beginning in the last decade, ethnic return migration, the newest reason for immigrating. A selective immigration policy also affects the demographic consistency of the immigrant population. Selectivity has precluded chain immigration, which has created immigrant communities in other countries where immigration is or has been part of labor policy. There are no extensive immigrant communities in Finland, so newcomers arrive without the ethnic networks that would make their integration easier. The new immigrant encounters the receiving society head-on, "naked", without the alleviating support of an ethnic community.

\footnotetext{
2 During the previous economic upswing in the late 1980 s, minor efforts on behalf of recruiting foreign workforce took place in sectors plagued by a labor shortage, namely construction and private services. These activities ceased quickly as the recession began.
} 
The aim of this article is to investigate the status of immigrants in the Finnish labor market, which is undergoing restructuring, and how different background factors individual and structural - are shaping it. This article is part of a larger research project whose results have been published earlier in Finnish (Forsander 2002). Even though several studies and reports financed by the Ministry of Labor and other authorities have been published, the tradition of academic research concerning the integration of immigrants is still very weak in Finland. This project is the first extensive academic research concerning immigrant integration into the Finnish labor market.

The age structure of the immigrants differs from that of the population as a whole. A majority of the immigrant population is of working age, and the single largest group comprises those aged 25-34 years. The share of the elderly among the immigrants is small, reflecting the recentness of immigration as a phenomenon. The proportion of women among immigrants in 1998 was approximately 49 percent. Within different immigrant groups, the ratio of men and women varies greatly, which demonstrates the selectivity of immigration policies. The significance of marriage to a Finnish citizen as grounds for immigration can be seen in the variation in gender distribution among different nationality groups: Finnish citizens have generally found wives in Russia and Estonia and husbands in Turkey and Morocco. In these nationality groups, the gender distribution is skewed. A large group among spouses of Finnish citizens is made up of Swedish nationals, a majority of whom are ethnically Finnish return migrants from Sweden. (Statistics Finland 2002, 13.)

Children make up about one-fifth of all immigrants, the same proportion as among the rest of the population in Finland. Especially among people who came as refugees there are a lot of children under the age of 15. For example, among immigrant groups from Somalia, Iraq and Kosovo, nearly half are children. (Statistics Finland 2002, 11, 17.) The high number of children under 15 in these groups is partly due to large families, but also to the fact that both parents are foreign nationals and therefore the children receive their parents' citizenship and language. In families where one parent is a Finnish citizen and the family resides in Finland, the children usually get Finnish citizenship and are registered as speaking Finnish or Swedish and do not show up in statistics on foreign citizens or foreign-language speakers.

In Finland, as elsewhere, immigrants have concentrated in large cities. Half of all foreign citizens live in the southern areas of the country. There immigrants have concentrated in the area of the capital, especially in Helsinki itself (Statistics Finland 2002, 27-29).

Toward the end of the last decade the number of immigrants who had received Finnish citizenship soared rapidly, as many who came early in the decade were granted citizenship. Finnish citizenship laws are fairly liberal: to be eligible to apply, an immigrant must reside in the country permanently for at least three or five years. Once a 
Finnish citizen, a person with an immigrant background has the same rights as all other Finnish citizens. However, in Finland like in many other EU countries the Citizenship Act is under renewal and new legislation will make double citizenship possible.

\section{Ethnicity, immigration and the labor market}

Especially in countries with a high volume of immigration, different immigrant groups often concentrate in particular sectors of the economy. Classic examples of this are Chinese laundromats, the Irish in the New York City police force or ethnic restaurants and shops. With the help of mutual contacts and contacts in the country of origin, immigrant communities can create separate ethnic economies, enclave economies. Newcomers can make contacts and find employment within the sphere of the enclave economy at a point when their command of the language, culture and social contacts of the majority population is still at the fledgling level. Early on, Canadian sociologist John Porter (1965) showed with his vertical mosaic thesis that ethnic communities do offer immigrants possibilities, but limiting oneself only to networks within the ethnic community may become an obstacle to an immigrant's social advancement, because the possibilities offered by the ethnic community are more limited than those in the broader society.

However, there is controversy as to how well Anglo-American models of ethnic labor market segmentation succeed in describing the situation in European and especially Nordic societies. In Nordic societies a strong state, a universal welfare society and tight regulation of the labor market have prevented the creation of ethnic enclaves or ethnic economies. The most significant dividing lines in the labor market concern who succeeds in finding a job and under what conditions, and not so much the industrial sectors themselves as in Anglo-American societies, where the low wage level has kept the threshold to the labor market low.

The position of immigrants in society is determined by the structures of the receiving society. The Nordic welfare state is based on the ideal of national homogeneity, and social structures do not adapt easily in response to the growing diversity of lifestyles. In the Nordic societies, the threshold of labor market inclusion is high, which keeps unemployment high among immigrants. In spite of this, the Nordic welfare state has been successful in preventing poverty, though the danger of the ethnification of poverty does exist in Finland, as stated in the end of this article.

It seems that a more precise way to describe ethnic labor market segmentation in Nordic societies is to look at the quality of work contracts instead of the quality of workplaces. During the last few decades the traditional labor market system has witnessed a process of drastic restructuring. This restructuring process is a part of a wider social change taking place, called the political economy of insecurity by Ulrich 
Beck (2000). Most labor market researchers do agree that the epoch of full (paid) employment has come to an end ${ }^{3}$. Part-time and short-time work contracts and easy terminability of work contracts mean flexibility in using labor for the employer but insecurity for the employee. This process has its consequences for the welfare state, since its institutions and mechanisms are based on the ceaseless continuity of a labor market career and full employment. It is a paradox that the risk-sharing task of the welfare state is needed more than ever just when its foundation and legitimacy is in crisis because of the crisis of the full-employment society.

The central hypothesis of this study is that immigrants when entering the Finnish labor market and building their career are to a large extent vulnerable to the effects of labor market restructuring - part-time work, short-term work contracts and a fragmented labor market career. The assumption is that the position of immigrants on the labor market will improve with time in Finland, but this improvement requires support in the form of good employment also among the majority population.

The position of young people on the job market may compose a good focus of comparison with the immigrants' situation: it has been shown that young people who have recently graduated are having difficulties in stabilizing their work career (Sutela et al. 2001). It has also been stated that national origin constitutes one of the determining factors of labor market integration. It is also assumed that the restructuring of the job market will treat different immigrant groups differently. The ethnic attitudes of the majority are reflected in how immigrants are treated on the labor market and how their position evolves ${ }^{4}$.

\footnotetext{
${ }^{3}$ Ulrich Beck (e.g. 1999) has introduced the concept of a zombie-category, a category of the living dead, meaning a category of phenomena which exist without being able to disappear, even though they do not have a reflection in the real world anymore. According to Beck full employment and normal work contracts can be included in this kind of category. The zombie-category outlines public discourse and decisionmaking, even though time has passed by the reality it describes. As an example, the welfare state and its institutions are still built on the idea of full employment, even though the insecurity of work contracts has increased rapidly and what used to be called a "normal work contract" is becoming anomalous.

${ }^{4}$ Most of the studies concerning ethnic attitudes of Finns towards immigrants reflect a similar ethnic hierarchy: Western people are the most wanted as immigrants, whereas "visible" minorities, mostly from developing and refugee-sending countries are the least wanted (Jaakkola 1999; Söderling 1997).
} 


\section{Data and methods}

This study differs from many previous studies focusing on immigrant labor market integration, because it is based on longitudinal data. I follow a group of immigrants who arrived in Finland between 1989 and 1993 and examine their performance in the Finnish labor market during the 1990s.

The target group of this research comprises everyone of working age (15-64) who immigrated to Finland between 1989 and 1993, and who were neither Finnish nor Swedish citizens when settling in Finland. Swedish citizens were excluded because most of them are originally Finnish remigrants from Sweden. As described elsewhere (e.g. Statistics Finland 2002, 6-7) the selected timespan, 1989-93, was a phase of rapid growth in the Finnish immigrant population.

The quantitative material is based on two databases. The first set of data is provided by Statistics Finland and consists of socioeconomic characteristics in the target group described. The material covers anonymized information on the province of residence, year of birth, citizenship, gender, education, employment, occupation, year of immigration to Finland and income. To create a panel setting, the same information is available for each individual from the end of the year of immigration, the year 1996 or 1997. The data covers a 33 percent evenly distributed sample of the 31,500 individuals in the target group.

The second body of data is from the Ministry of Labor and its database covering all jobseekers registered at employment offices. A person might be registered as a jobseeker even while not being unemployed, but as merely willing to find alternative work. About half of the immigrants in the target group are in the Ministry of Labor register and a total of 12,000 are included in my data. This data includes more specific information on the education and employment of individuals and covers the target group's situation up to October 1999. Because these two databases from different sources partly overlap, they increase the validity and reliability of the study as a whole.

\section{Segmentation on the basis of the work contract}

The following is an examination of how working-age immigrants are segmented into different groups on the basis of their labor market career during their resettlement in Finland. The aim is to show what kinds of changes in labor market position have occurred in different immigrant groups during the 1990s. It is worth noting that the data does not reveal the quality of the work contract, e.g. whether the job is a permanent or a temporary one, nor does it reveal whether the job contract is governmentally subsidized or a so-called "normal" open market work contract. During the economic 
recession in the beginning of the 1990s a large number of unemployed persons, including immigrants, were employed especially in the public sector under short, temporary 6-10-month work contracts.

Labor market integration is operationalized using a variable describing labor market status (values: employed, unemployed, other). I have divided the target group into the following four groups: 1) those in a stable labor market career, 2) those in an unstable labor market career, 3) those in the margins of the labor market and 4) those outside the labor force. An immigrant was classified as being in a stable labor market career of he/she had been employed during the last two years, 1996 and 1997, of the three periods being examined, the immigration year (between 1989 and 1993), 1996 and 1997. When interpreted like this only five percent of the target group was in a stable labor market position. People were included in the unstable labor market career group when they had been employed for one of the last two years being studied, but had been unemployed or outside the labor force during the other. This group was rather big: 60 percent of the target group belonged to this group.

Those who had not been employed during any of the years being examined or who were employed only during the first or the second of the years being examined were classified as being in the margins of the labor market. This group consisted of 28 percent of the target group. Those outside the labor force include those who had been out of the labor force during all the years studied or only during the last two years studied. This group includes seven percent of the target group.

Table 1 describes the distribution of immigrants from the target group into labor market career types.

Table 1. The distribution of immigrants into labor market career types.

\begin{tabular}{lrr}
\hline Labor market career & N & \% \\
\hline Stable labor market career & 447 & 5 \\
Unstable labor market career & 5,095 & 60 \\
Margins of the labor market & 2,403 & 28 \\
Outside the labor force & 611 & 7 \\
\hline Total & $\mathbf{8 , 5 5 6}$ & $\mathbf{1 0 0}$
\end{tabular}

\section{Factors explaining the distribution of immigrants into different careers}

An examination was also made of the background factors explaining the division of immigrants into different labor market careers. The analysis was made using the MCA (Multiple Classification Analysis) application of variance analysis. MCA allows the 
use of categorical data, and it also allows the study of the variables' covariance and contrasts between the variables. In MCA one dependent variable and several independent variables are examined at the same time. The aim is to study how much of the dependent variable's variance the independent variables explain together and individually. MCA also produces standardized beta-coefficients: the larger the variable's coefficient, the better it explains the dependent variable's variance.

The immigrants' division into labor market career groups was studied in the following way. The labor market career variable was converted into four dummy variables, whose variance was explained using four different models. Each labor market career group, those in stable or unstable careers, those in a marginal position and those outside the labor market, was analyzed separately.

The variables selected for the MC-analysis were variables which according to earlier research explain the labor market position of immigrants, such as gender, age, educational level, national origin and immigration year. The variable national origin of education was included because some studies (e.g. Friedberg 2000) show that it has a positive impact on the immigrant's labor market position.

Figure 1 on next page describes the proportion of immigrants in different labor market careers on the basis of their origin. The origin-variable is artificially constructed on the basis of criteria based partly on geography and partly on reasons for immigration. The category countries sending refugees includes immigrants from countries like Afghanistan, Iran, Iraq, Somalia, Vietnam and the former Yugoslavia. The category Western countries includes the Nordic countries, the rest of Europe, Oceania and the Americas. South and Central America or Eastern Europe are not conventionally categorized as Western countries, but the proportion of Southern and Central Americans is so small in the data $(\mathrm{N}=102)$ and also in Finland, in general, that this causes no distortion of the results. Earlier studies have shown that the position of Eastern Europeans in the Finnish labor market is quite similar to that of the other Europeans, and this justifies setting these two groups together (Forsander and AlitolppaNiitamo 2000). The other groups, such as Africa, Asia and the former Soviet Union, were formed on a geographical basis.

All four labor market career models were significant. The most important explanatory variables were national origin of education, educational level and the origin of the immigrant. However, variables like age, immigration year and gender proved to be weaker as explanatory variables. The proportion of the variance explained was low in all four labor market career models, varying between 0.011 and 0.068 . Nevertheless, the results are statistically very significant, and the suggestive significance of the results in regard to the whole should be taken into consideration, even with statistically less significant results. In social studies even weak signals can tell something essential about a studied entity (Heikkilä 1998, 189). 
Figure 1. Immigrants with different labor market careers on the basis of their origin $(\mathrm{N}=8,556)$.

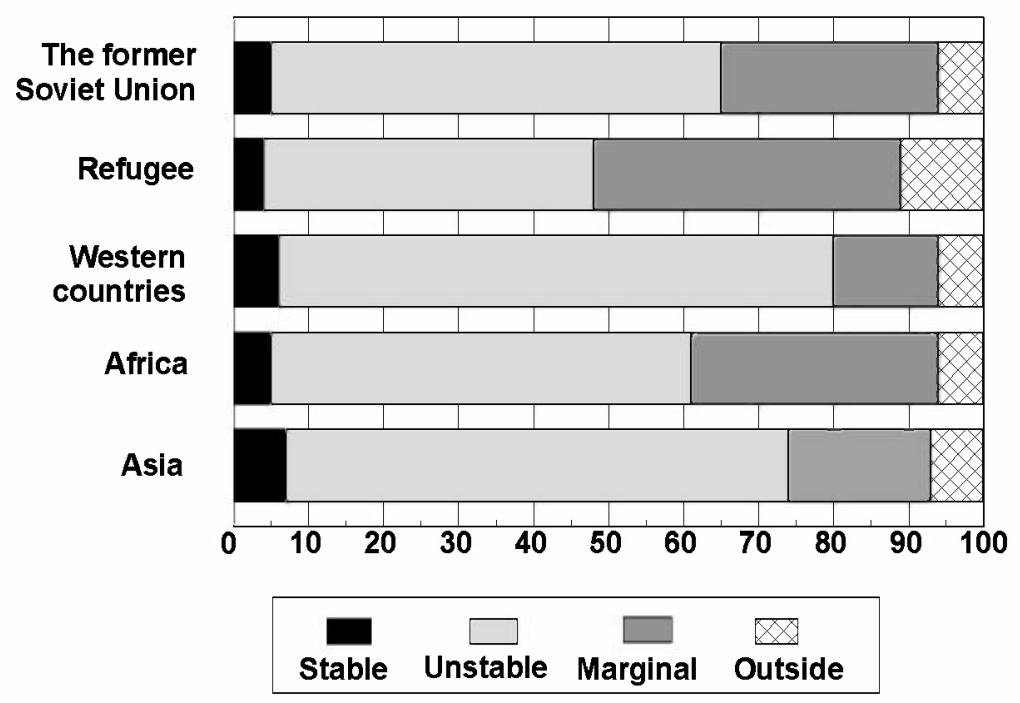

Table 2 describes background factors of different kinds of labor market careers on the basis of the MC-analysis. Detailed results are presented in Appendix 1. Table 2 shows the variables which best divided immigrants into different groups in the analysis of different labor market career models. The background factors of the labor market career -column includes the values of variables or background factors which describe immigrants in the labor market career in question more often than other background factors do.

Table 2. Background factors of the labor market career types.

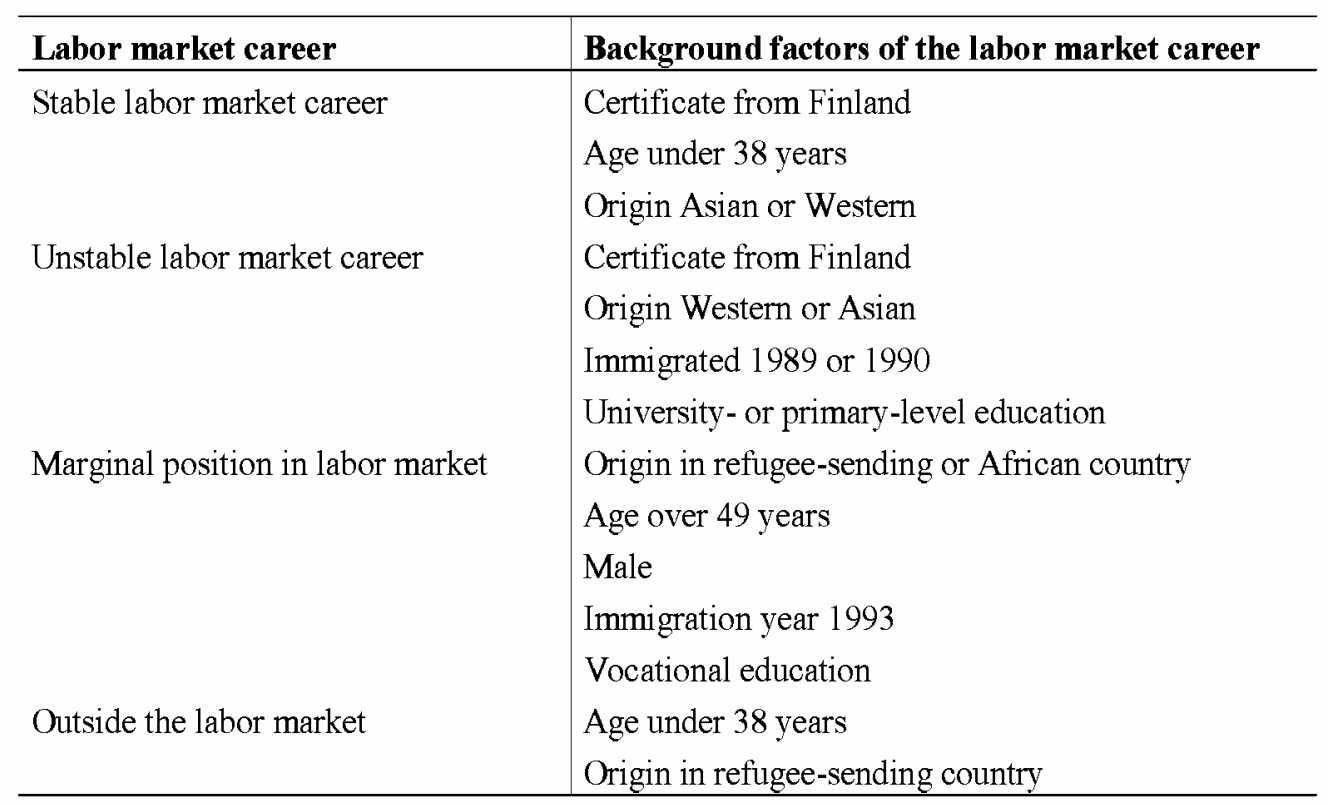


Stable labor market career was explained best by national origin of education, age and origin, while gender, immigration year and level of education were under the significance level, which was 0.050 . Those in a stable labor market career were characterized by having a certificate from Finland, age less than 38 years and an Asian or Western origin. The level of education -variable gave indicative results: those in a stable labor market career had a university-level education more often than a vocational-level education. An interesting detail is that gender did not distinguish between those in a stable labor market career; however, the proportion of women in this group was actually slightly bigger than the proportion of men.

An unstable labor market career was explained best by national origin of education, origin, immigration year and educational level, while gender and age remained under the significance level. Those in an unstable labor market career were characterized by a certificate from Finland, Western or Asian origin, immigration year 1989 or 1990 and university-level or - at the other extreme - an unknown or primary-level education. Gender or age do not significantly distinguish between those in an unstable labor market career; however, in older age groups there are slightly fewer with an unstable labor market career than among younger age groups.

Among those in the margins of the labor market all the explanatory variables were very significant. Origin, level of education and national origin of education were the strongest independent variables. Refugees and Africans, the aged, men and those with a lower education or educated outside Finland were more often in a marginal position, as were those who came later during the target timespan.

The outside the labor market - group is distinguished best by origin and age, while the other variables remain under the significance level . Refugees have, more often than the other groups, remained outside the labor market as long as they have lived in Finland, which correlates with the marked proportion of students and housewives in this group. Also the younger the age group in question, the bigger the proportion of those outside the labor market, most likely students and housewives. It seems that maternity keeps immigrant women outside of the labor market only periodically and only in nationality groups which have immigrated as refugees and which have a high fertility rate, such as Somali and Iraqi nationals.

Independent variables were also examined separately comparing their values with each other in different labor market career types. The origin-variable was the best predictor of labor market career for those in a marginal position and the second best after the education level-variable for those in an unstable labor market career. It was also one of the strongest explanatory variables in the other groups. Ethnic hierarchy in the division of immigrants into different labor market careers supports earlier findings from the field: immigrants from Western countries have the strongest position in 
the labor market, with Asians in second place, followed by immigrants from the former Soviet Union and Africa, with refugees taking last place in the labor market.

The age-variable showed that regarding age, immigrants are in a situation similar to that of the native workforce: younger persons are in a better position compared to members of older generations. Similar results have been found in other countries. In a study made in Denmark on the living conditions of immigrants, it was found that good skills in the Danish language, good health and age between 25-49 were the main factors advancing an immigrants' integration into the labor market (Shultz-Nielsen 2000). Earlier I have shown that the education level among immigrants over 45 years is lower than in the younger age groups (Forsander 2002,123). The same study showed that older, less educated immigrants have typically done manual work during their labor market career in the countries of origin. Especially most of the older immigrants from the former Soviet Union have a long career in labor-intensive industrial work. Therefore the health of the older immigrants is too weak to allow them to perform the tasks available to them in the Finnish labor market, e.g. menial tasks in services such as cleaning and catering. However, half of all the immigrant jobseekers over 50 years of age were marked as having some kind of a handicap in the register of the Ministry of Labor.

The immigration year -variable showed that those who immigrated during the first years, 1989 and 1990, of the targeted time-span, were a bit more often in stable or unstable labor market careers than those who immigrated later. One explanation for this is not only the positive effects of the longer time spent in a resettlement country, but also the difference between the immigrant vintages ${ }^{5}$.

The educational level -variable shows that the labor market careers of the highly educated are slightly more often stable than those of those with less education. However, this difference is not significant.

More interesting is that the variable national origin of education divides immigrants clearly. The results show that it is significant for the immigrants' working career whether his or her certificate has been acquired in Finland. Education attained in Finland seems to help immigrants cross the threshold into the labor market. This observation is supported by other studies as well. Education, as well as other human capital brought with the resettling immigrant, suffers from inflation in the labor market of the new country (Borjas 1994). The value given to an education varies according to the country where it was acquired, but, according to earlier studies, local education is valued most highly in the labor market of the resettlement country (Friedberg 2000; Schulz 1998, 240-241).

5 The concept of vintage was introduced by Egon F. Kunz (1973). He described how refugee groups fleeing persecution differ on the basis of the time they flee and the social class they belong to. 
Education achieved in other countries is mostly useless, if language skills helping to adapt the learned skills are lacking (Waxman 2001). Especially in the academic professions language skills are needed on a very abstract level, which leads to employment difficulties and lowering of the social status of academics in the labor market of the resettlement country. It often takes years before language skills are good enough so that further education can be fully utilized (Bauer \& Zimmerman 1998). According to research carried out in the United States by Espensade and Fu (1997) the impact of the place where the certificate is attained is based on improvement in one's language skills, which is a result of living and studying in a given language environment.

\section{Conclusion and discussion}

This study shows that it not possible to find a single variable that by itself could explain the labor market status of immigrants. Instead, a model consisting of multiple variables is more successful in illustrating the labor market status of immigrants.

Those immigrants who have been employed almost since the beginning of their time of residence in Finland made up only five percent of those studied in 1997. Members of this group are considered to have a stable labor market status. The majority of the immigrants studied were in an unstable $(60 \%)$ or marginal $(28 \%)$ labor market position in the Finnish labor market, and seven percent were outside of the labor force.

In brief, the results show that national origin is relevant to the labor market integration of new immigrants. The national origin of the immigrants is the strongest variable explaining the immigrants' labor market career in statistical data. Who then are the losers or winners in this competition for decent employment? The labor market status of refugees and of those who immigrated from developing countries was shown to be the weakest, whereas it proved strongest among Asians and especially immigrants from Western countries. This can be interpreted to mean that immigrants are affected by the global economic order and by the unequal division of possibilities that shape the ethnic and social hierarchy in the receiving society.

Educational background only partially explains labor market status. More important than the amount of education is the labor market value of one's education. It was shown that a certificate attained in Finland offered a better starting point for employment than a certificate acquired elsewhere. The result can be interpreted using the social trust -value of education. While studying in a resettlement country, the immigrant gathers useful human capital: not only professional skills but also language and cultural skills (Alitolppa-Niitamo 2002; Friedberg 2000). Through education in the resettlement country it is also possible to establish professional social contacts and 
networks, which have been shown to be a crucial element for employment and career building. Social-network analysts like Granovetter $(1973 ; 1995)$ have stated that a remarkable share of all job positions are filled through informal networks, with social contacts also playing a crucial role in promotions.

It is also shown that majority population employers tend to downgrade education achieved abroad, especially in countries considered to be less important in the global hierarchy. This downgrading done by employers can be a result of mistrust. Employers know what domestic degrees consist of and what kind of knowhow can be expected from the holder of a degree. When an immigrant has a foreign degree, it is more difficult to evaluate what kind of knowhow it is composed of.

These results show that immigrants who have resided in Finland less than a decade are extremely weakly attached to the labor market. A weak attachment to the labor market causes dependency on social income transfers. In 1997, 61 percent of the immigrants studied received taxable social income transfers, and the most typical form of the income transfers was the unemployment benefit. Unstable labor market status affecting the majority of immigrants means that their labor market career consists of temporary work contracts, unemployment, courses and other employment measures, with these different statuses prevailing for short periods and then changing again. Sources of income also differ constantly. Income consists of periodical, irregular wages or salary, mostly on a minimum-wage level because immigrants are overrepresented in low-paid, blue-collar jobs, and of various income transfers. Because of the low salaries and temporality of work contracts, income transfers often leave people below the minimum income norm level, which means that families, in particular, are often entitled to means-tested social assistance. In a universal Nordic welfare state like Finland instability of income leads to a spiral of bureaucracy and welfare dependency. The immigrant's role in a universal welfare state is too often the role of an object and a passive welfare-benefit recipient.

The differences in the distribution of social income transfers between and within different citizenship groups were significant, however. Most of the social income transfers went to those citizenship groups that had the highest number of children and the lowest employment rate. These groups were mainly refugees.

The unstable labor market status of the majority of immigrants means that they are extremely vulnerable to the labor market effects of economic trends and to structural changes in production. In this respect, the labor market position of immigrants remains the same as that of the majority of young people and the handicapped. Immigrants are overrepresented among the segment of people who are the last to be hired and the first to be let go, at the mercy of economic highs and lows. Their labor market position is therefore like a seismograph of social changes. The immigrants' labor market position reveals to us that they are trapped in the margins of Finnish society: they 
are not fully included but not completely excluded either. For immigrants, the risk of being marginalized in the labor market is, therefore, even greater in the second generation. There is no reason not to believe that marginality or poverty would not have a tendency to be socially inherited as it is in the majority population.

\section{References}

Alitolppa-Niitamo, Anne. 2002. The generation in-between: Somali youth and schooling in metropolitan Helsinki. Intercultural Education, vol 13:3. 275-90.

Bauer, Thomas \& Zimmerman, Klaus F. 1998. Occupational Mobility of Ethnic Migrants. Research on Immigration and Integration in the Metropolis. Working Paper Series 98-11. Vancouver: Vancouver Centre of Excellence

Beck, Ulrich. 1999. Työyhteiskunnan tuolle puolen. Janus 7(1): 257-266

Beck, Ulrich. 2000. The Brave New World of Work. Cambridge: Polity Press.

Espenshade, Thomas J. \& Fu, Haishan. 1997. An analysis of English-Language Proficiency among U.S. Immigrants. American Sociological Review Vol. 62. 288-305.

Forsander, Annika. 2002. Luottamuksen ehdot. Maahanmuuttajat 1990-luvun suomalaisilla työmarkkinoilla. [ Conditions of trust. Immigrants in the Finnish labor market of the 1990s.] Väestöntutkimuslaitoksen julkaisusarja D 33. Helsinki: Väesöntutkimuslaitos, Väestöliitto.

Forsander, Annika \& Alitolppa-Niitamo, Anne. 2000. Maahanmuuttajien työllistyminen ja työhallinto - keitä, miten ja minne? Työhallinnon julkaisu 242. Helsinki: Työministeriö.

Friedberg, Rachel M. 2000. You Can't Take It with You? Immigrant Assimilation and the Portability of Human Capital. Journal of Labor Economics 18( 2): 221-252.

Granovetter, Mark. 1973. The Strength of Weak Ties. American Joumal of Sociology 78 (6): $1360-1380$.

Granovetter, Mark. 1995. The Economic Sociology of Firms and Entrepreneurs. In: The Economic Sociology of Immigration. Essays on Networks, Ethnicity, and Entrepreneurship, edited by Alejandro Portes, pp. 128-165. New York: Russell Sage Foundation.

Heikkilä, Tarja. 1998. Tilastollinen tutkimus. Helsinki: Edita.

Jaakkola, Magdalena. 1999. Maahanmuutto ja etniset asenteet. Työpoliittinen tutkimus 213. Helsinki: Edita.

Kunz, Egon F. 1973. The Refugee In Flight: Kinetic Models and Forms of Displacement. International Migration Review 7(2):125-146

Nieminen, Mauri . 1998. Tilastokeskuksen rekisterit väestöntutkimuksen perusaineistona. In: Rekisteriaineistot yhteiskunta- ja terveystutkimuksessa, edited by Tapani Valkonen, Seppo Koskinen and Tuija Martelin, pp. 80-101. Helsinki: Gaudeamus.

Porter, John. 1965. The Vertical Mosaic. An Analysis of Social Class and Power in Canada. Toronto: University of Toronto Press.

Schultz, Paul. 1998. Immigrant quality and assimilation: A review of the US literature. Journal of Population Economics 11, pp. 239-52.

Schultz-Nielsen, Marie Louise. 2000. Hvilke individuelle faktorer har betydning for integrationen på arbejdsmarkedet? In: Integration i Danmark omkring årtusindskiftet. Invandrernes mode med arbejdsmarkedet og velfcerdssamfundet, edited by Gunnar Viby Mogensen \& Poul Chr. Matthiessen, pp. 127-159. Aarhus: Aarhus Universitetsforlag.

Statistics Finland - Tilastokeskus. 2002. Ulkomaalaiset ja siirtolaisuus 2001. Foreigners and international migration 2001. Väestö 2002:8. Helsinki: Statistics Finland. 
Sutela, Hanna \& Vänskä, Jukka \& Notkola, Veijo. 2001. Pätkätyöt Suomessa 1990-luvulla. Työmarkkinat 2001. Helsinki: Tilastokeskus.

Söderling, Ismo. 1997. Maahanmuuttoasenteet ja elämänhallinta. Väestöntutkimuslaitoksen julkaisusarja D 30. Helsinki: Väestöntutkimuslaitos, Väestöliitto.

Waxman, Peter. 2001. The Economic Adjustment of Recently Arrived Bosnian, Afghan and Iraqi Refugees in Sydney, Australia. International Migration Review 35( 2):472-505.

\section{Appendix 1}

Background factors affecting the labor market career of immigrants. in 1997, MCanalysis 1 , stable labor market career. Values of dependent variable $1=$ stable labor market career, $0=$ others $(\mathrm{N}=8,556$.

\begin{tabular}{|c|c|c|c|c|c|c|}
\hline & $\mathbf{N}$ & $\begin{array}{l}\text { Group } \\
\text { mean }\end{array}$ & $\begin{array}{l}\text { Adjusted } \\
\text { group mean }\end{array}$ & Eta & Beta & Sig \\
\hline \multicolumn{7}{|l|}{ Sex } \\
\hline Male & 4,530 & .0503 & .0500 & .009 & .011 & .337 \\
\hline Female & 4,026 & .0544 & .0548 & & & \\
\hline \multicolumn{7}{|l|}{ Age. year 1997} \\
\hline $59-$ & 434 & .0161 & .0203 & .056 & .051 & .000 \\
\hline $49-58$ & 690 & .0377 & .0385 & & & \\
\hline $39-48$ & 1,975 & .0471 & .0477 & & & \\
\hline $29-38$ & 3,890 & .0540 & .0534 & & & \\
\hline-28 & 1,567 & .0708 & .0700 & & & \\
\hline \multicolumn{7}{|l|}{ Immigration year } \\
\hline 1989 & 693 & .0491 & .0450 & .018 & .013 & .830 \\
\hline 1990 & 1,325 & .0589 & .0569 & & & \\
\hline 1991 & 2,547 & .0518 & .0517 & & & \\
\hline 1992 & 1,934 & .0548 & .0538 & & & \\
\hline 1993 & 2,057 & .0472 & .0510 & & & \\
\hline \multicolumn{7}{|l|}{ National origin of education } \\
\hline \multicolumn{7}{|l|}{ Finland } \\
\hline Abroad & 910 & .1011 & .0907 & .077 & .061 & .000 \\
\hline \multirow[t]{2}{*}{ Unknown } & 3,268 & .0508 & .0439 & & & \\
\hline & 4,378 & .0432 & .0505 & & & \\
\hline \multicolumn{7}{|l|}{ Level of education } \\
\hline $\begin{array}{l}\text { Max. primary level or unknown } \\
\text { Secondary level }\end{array}$ & 4,574 & .0439 & .0451 & .041 & .038 & .230 \\
\hline \multirow[t]{2}{*}{ Tertiary level } & 2,472 & .0591 & .0564 & & & \\
\hline & 1,510 & .0662 & .0670 & & & \\
\hline \multicolumn{7}{|l|}{ Origin } \\
\hline Former Soviet Union & 4,248 & .0520 & .0532 & .045 & .049 & .001 \\
\hline Refugee-sending countries & 1,477 & .0352 & .0327 & & & \\
\hline \multicolumn{7}{|l|}{ Western countries } \\
\hline Africa & 1,215 & .0593 & .0616 & & & \\
\hline \multirow[t]{2}{*}{ Asia } & 518 & .0483 & .0436 & & & \\
\hline & 1,098 & .0701 & .0685 & & & \\
\hline Multiple $\mathrm{R}^{2}$ & .011 & & & & & \\
\hline Multiple R & .000 & & & & & \\
\hline
\end{tabular}




\section{Appendix 2}

Background factors affecting the labor market career of immigrants. in 1997. MCanalysis 2 . unstable labor market career. Values of dependent variable $1=$ unstable labor market career. $0=$ others $(\mathrm{N}=8,556$.

\begin{tabular}{|c|c|c|c|c|c|c|}
\hline & $\mathbf{N}$ & Group mean & $\begin{array}{c}\text { Adjusted } \\
\text { group mean }\end{array}$ & Eta & Beta & Sig \\
\hline \multicolumn{7}{|l|}{ Sex } \\
\hline Male & 4,530 & .5903 & .0500 & .011 & .014 & .208 \\
\hline Female & 4,026 & 6013 & .0548 & & & \\
\hline \multicolumn{7}{|l|}{ Age. year 1997} \\
\hline $59-$ & 434 & .5922 & .5692 & .012 & .021 & .460 \\
\hline $49-58$ & 690 & .5855 & .5716 & & & \\
\hline $39-48$ & 1,975 & .5954 & .5934 & & & \\
\hline $29-38$ & 3,890 & .6008 & .6020 & & & \\
\hline-28 & 1,567 & .5877 & .5999 & & & \\
\hline \multicolumn{7}{|l|}{ Immigration year } \\
\hline $1989^{\circ}$ & 693 & .6508 & .5908 & .079 & .043 & .003 \\
\hline 1990 & 1,325 & .6332 & .6038 & & & \\
\hline 1991 & 2,547 & .6125 & .6204 & & & \\
\hline 1992 & 1,934 & .5941 & .5928 & & & \\
\hline 1993 & 2,057 & .5328 & .5634 & & & \\
\hline \multicolumn{7}{|l|}{ National origin of education } \\
\hline Finland & 910 & .6440 & .7367 & .125 & .118 & .000 \\
\hline Abroad & 3,268 & .5177 & .6166 & & & \\
\hline Unknown & 4,378 & .6434 & .5504 & & & \\
\hline \multicolumn{7}{|l|}{ Level of education } \\
\hline $\begin{array}{l}\text { Max. primary level or } \\
\text { unknown }\end{array}$ & 4,574 & .6484 & .6882 & .125 & .205 & .000 \\
\hline Secondary & 2,472 & .5077 & .4704 & & & \\
\hline Tertiary & 1,510 & .5788 & .5192 & & & \\
\hline \multicolumn{7}{|l|}{ Origin } \\
\hline Former SU & 4,248 & .5920 & .6008 & .179 & .170 & .001 \\
\hline Refugee-sending countries & 1,477 & .4428 & .4435 & & & \\
\hline \multicolumn{7}{|l|}{ Western countries } \\
\hline Africa & 1,215 & .7383 & .7300 & & & \\
\hline \multirow{2}{*}{ Asia } & 518 & .5637 & .5609 & & & \\
\hline & 1,098 & .6712 & .6467 & & & \\
\hline Multiple $\mathrm{R}^{2}$ & .054 & & & & & \\
\hline Multiple R & .000 & & & & & \\
\hline
\end{tabular}




\section{Appendix 3}

Background factors affecting the labor market career of immigrants, in 1997, MCAnalysis 4, outside the labor market. Values of dependent variable 1= outside the labor market, $0=$ others $(\mathrm{N}=8,556$.)

\begin{tabular}{|c|c|c|c|c|c|c|}
\hline & $\mathbf{N}$ & Group mean & $\begin{array}{c}\text { Adjusted } \\
\text { group mean }\end{array}$ & Eta & Beta & Sig \\
\hline \multicolumn{7}{|l|}{ Sex } \\
\hline Male & 4,530 & .0684 & .0668 & .012 & .019 & .093 \\
\hline Female & 4,026 & .0748 & .0766 & & & \\
\hline \multicolumn{7}{|l|}{ Age year 1997} \\
\hline 59- & 434 & .0392 & .0439 & .074 & .067 & .000 \\
\hline $49-58$ & 690 & .0377 & .0407 & & & \\
\hline $39-48$ & 1,975 & .0572 & .0581 & & & \\
\hline $29-38$ & 3,890 & .0761 & .0758 & & & \\
\hline-28 & 1,567 & .1015 & .0984 & & & \\
\hline \multicolumn{7}{|l|}{ Immigration year } \\
\hline 1989 & 693 & .0722 & .0817 & .025 & .025 & .271 \\
\hline 1990 & 1,325 & .0566 & .0620 & & & \\
\hline 1991 & 2,547 & .0746 & .0749 & & & \\
\hline 1992 & 1,934 & .0750 & .0762 & & & \\
\hline 1993 & 2,057 & .0734 & .0652 & & & \\
\hline \multicolumn{7}{|l|}{ National origin of education } \\
\hline Finland & 910 & .0824 & .0571 & & & \\
\hline Abroad & 3,268 & .0753 & .0602 & .022 & .045 & .413 \\
\hline Unknown & 4,378 & .0662 & .0828 & & & \\
\hline \multicolumn{7}{|l|}{ Level of education } \\
\hline Max. primary or unknown & 4,574 & .0656 & .0549 & .033 & .069 & .136 \\
\hline Secondary level & 2,472 & .0845 & .0921 & & & \\
\hline Tertiary level & 1,510 & .0675 & .0874 & & & \\
\hline \multicolumn{7}{|l|}{ National origin } \\
\hline Former SU & 4,248 & .0629 & .0638 & .067 & .062 & .000 \\
\hline Refugee-sending countries & 1,477 & .1090 & .1060 & & & \\
\hline \multicolumn{7}{|l|}{ Western countries } \\
\hline Africa & 1,215 & .0634 & .0661 & & & \\
\hline \multirow[t]{2}{*}{ Asia } & 518 & .0579 & .0555 & & & \\
\hline & 1,098 & .0692 & .0678 & & & \\
\hline Multiple R2 & .011 & & & & & \\
\hline Multiple R & .000 & & & & & \\
\hline
\end{tabular}

